well union to medical men for tender, the election being stated to take place on Tues. day, the 16th. The practitioner who held the district No. 2 in the last year being only a L. A. C. : intending myself to tender for the same, and being a L. A.C. and a M. R. C.S., 1 addressed a letter on the sub. ject to the poor-law commissioners, asking them if a candidate possessing the lastnamed qualifications was not to be preferred to one only holding the first. The reply I have enclosed, but I must confess it does not give me the least satisfaction. I still am of opinion, although at this time I cannot find one to the contrary, that they have at some time recognised it as a principle to be acted upon in the election of medical officers to a union, that if a man offered himself having a diploma from the College and a licence from the Apothecaries' Company, the preference should be given to him, unless in practice previous to 1815 .*

$I$ attended at Southwell on the day of election; and, although the guardians had offered it to competition, it appears they had fixed their own sums at which such of the different districts should be let : not letting such appear in the advertisement, the successful man for No. 2 being the old officer. Why, may $I$ inquire, was not $I$ asked if $I$ would accept it on the same terms (why I make this remark will presently appear), my qualification being superior. For No. 6 three tendered, one being the party to whom No. 2 was awarded, at $18 l$, the others being both legally qualified; one tendered at $19 \mathrm{l}$., the other at $21 l$. Will you believe it? Although they did pledge themselves not to accept the lowest tender, they called in the man at $21 l$., saying, "If you choose to take it at $19 l$., you may have it;" to which he immediately consented. The same thing being done in the district No. 2 , for which $I$ tendered at $28 l$, the successful candidate at 25l. I cannot understand how they came to such a decision, in face of the advertisement; to me it appears perfectly inexplicable, and to be both very unjust and extremely dishonest. I am, Sir, your obedient servant,

John B. Samuel.

Sutton-upon-Trent, Newark, March 28, 1841.

* The commissioners have never adopted any such rule. On the contrary, the "qualification" and competency of the candidate seem always to have been regarded as objects which were secondary to the sum per annum at which he would profess to undertake the duties of the office. In many cases, if a person could be obtained who was not unlikely to ease the rates by letting the sick, the infirm, and the useless "die off," the preference was given to such an one. This is called "weeding out the population."
" QUALIFICATION OF MEDICAL OFFICERS.

" Poor-law Commission-office,

Somerset House, 15 th March, 1841.

" Sir :-In answer to the inquiry contained in your letter of the 8 th instant, respecting the qualification of a medical officer, the poor-law commissioners desire to state that they guide themselves entirely on this sub. ject by the 109th section of the Poor-law Amendment Act, which defines a medical officer to be any person duly licensed to practise as a medical man.

"The commissioners presume this defini. tion to include every description of legally. qualified practitioner, and the commissioners have neither the power nor the inclination to confine the qualification within narrower limits.

"Signed, by order of the Board, "E. Chadwick, Secretary.

"To J. B. Samuel, Esq., Newark."

\section{PROFESSOR OWEN'S LECTURES.}

\section{To the Editor of THE LANCET.}

SIR :-As I did not see your reporter present at the College of Surgeons yesterday, allow me to communicate to your readers a brief description of the discourse delivered by Mr. Owen. The professor, at the conclusion of the first lecture, which contained a recapitulation of $w$ hat he had gone through in former courses, announced that he would yesterday commence the interesting subject of comparative and fossil osteology, and hinted that his mode of treating the subject would relieve it somewhat of that dryness which is usually connected with it Accordingly, a goodly display of members as. sembled yesterday, several being elders of the profession, and not a few provided with note-books and black-leads. It will scarcely be credited, that Mr. Owen occupied the whole hour in a demonstration of the bones of the human skeleton, of so purely an ele. mentary a nature, that the veriest tyro of the profession who had attended but one course of lectures would have learned nothing from the lecture. The manifest, and I may say insulting absurdity of pointing out to the " learned" members of the college, which was the squamous, which the petrous portion of the temporal bone, the arched form of the skull, and the number of bones of which the lower extremity is composed, ought to have been at once evident. The wearjed looks of those who were present testified how foolish was the proceeding; and I can only compliment them for their politeness, in not otherwise manifesting to the lecturer how much he had mistaken the nature of the office he had to fulfil. It is true that $\mathrm{Mr}$. Owen apologised for bringing before his audience a demonstration that was familiar to them even in their pupillage, upon the 